R.J.S. Robinson MB B CH FRCP(C), I.R. Metcalf MB BS FFARACS FRCP(C)

\title{
Hypertension after epidural meperidine
}

The use of epidural opiates, unike the use of epidural local anaesthetics, is considered to have little, if any, effect on the cardiovascular system. A 76-year-old man with a fiail chest injury was given a iumber epidural injection of meperidine. During the injection he suddenly complained of feeling cold, shivered vigorously and became tachypneic. His arterial blood pressure rose from 170170 to 3001110 ; his pulse rate rose to $150 / \mathrm{min}$. The patient was severely hypertensive for 40 minutes until treated with intravenous phentolamine. There is increas ing evidence in the literature implicating the involvement of endogenous opiates in the central control mechanisms of blood pressure control.

Epidural meperidine is routinely used in the pain management of flail chest injury in our institution. It provides excellent analgesia; patients are able to cough well, and breathe deeply without pain. Fifty to $100 \mathrm{mg}$ of meperidine in 15 to $25 \mathrm{ml}$ of normal saline is given via a lumbar epidural catheter, every three to four hours, as required. Only an occasional patient, with severe lung contusion causing respiratory failure, is treated with controlled respiration and positive and expiratory pressure. ${ }^{1}$

One of the significant advantages of epidural meperidine is the lack of the cardiovascular instability seen with the use of epidural local anaes. thetics: patients are able to sit up, and move around without significant blood pressure changes. Recently, however, we encountered a case of sudden

\section{Key words}

ANALGESICS: meperidine, epidural; COMPLICATIONS: hypertension.

From the Department of Annesthesia, the Montreal General Hospital, Montreal, Quebec.

Address correspondence to: Dr. R.J.S. Robinson, Department of Anaesthesia, The Montreal General Hospital, 1650 Cedar Avenue, Montreal, P.Q. H3G 1 A4. sustained hypertension, tachycardia and shivering during administration of epidural meperidine.

\section{Case report}

A 76-year-old man, involved in a motor vehicle accident, was admitted to the surgical intensive care unit. His injuries included bilateral rib fractures, with a prominent right flail segment, right haemothorax, right lower lobe contusion and electrocardiogram and CPK enzyme changes consistent with cardiac contusion. He had a past history of hypertension for which he was taking hydrochlorthiazide $50 \mathrm{mg}$ daily and metoprolol $50 \mathrm{mg}$ twice daily. The last dose of metoprolol was taken 30 hours previously and further beta adrenergic blocker therapy was not given in the intensive care unit. There was no history of use of monoamine oxidase inhibitors.

An epidural catheter, positioned in the L1-2 interspace had to be withdrawn as it entered an epidural vein; it was reinserted in the L2-3 space. Meperidine $50 \mathrm{mg}$ in $20 \mathrm{ml}$ of normal saline, when injected through the catheter, resulted in good analgesia, improved ability to cough, and a fall in respiratory rate from 28 to 20 . Thereafter, a one centimeter withdrawal of the epidural catheter was required, when blood tinged fuid appeared in it.

Seven hours later the patient complained of pain. During the injection of meperidine $50 \mathrm{mg}$ in $15 \mathrm{ml}$ of saline, he suddenly complained of feeling "freezingcold," was shivering vigorously, and became tachynoeic (32 breaths per minute). His blood pressure, monitored by an arterial line, had acutely risen from $170 / 70$ to $300 / 110$, and his pulse rate had risen from 126 to 150 beats per minute.

The injection of meperidine was stopped after $7 \mathrm{ml}$ of the solution had been given. The blood pressure was checked by the inflation of a blood presure cuff to confirm that the arterial line was reading correctly. Propranolol $1 \mathrm{mg}+1 \mathrm{mg}$ was given intravenously, and after five minutes the pulse rate fell to 130 . The patient's blood pressure remained high, decaying to 280 systolic, then 250 systolic over a 40 -minute period. The patient 
continued to shiver violently during this time. Phentolamine $5 \mathrm{mg}$ was given 40 minutes after the onset of hypertension, and the patient's blood pressure rapidly fell from 250 to 90 systolic. Fifteen minutes later his blood pressure was 160 systolic and then remained close to the pre-event values. The patient felt well, and required no analgesia for four hours.

The anaesthetist checked the catheter and noted that there was a little blood tinged fuid in it, but he was unable to aspirate blood or CSF. The catheter was removed.

On exhaustive cross-checking we were satisfied that only preservative-free meperidine, in normal saline, without adrenalin, had been given, using a fresh needle and syringe. The normal saline used was taken from a fresh unopened bottle identical to the saline used in the first injection.

\section{Discussion}

The hypertensive response to the injection of epidural meperidine in this patient was unexpected. The rise in blood pressure was acute, sustained, and significant enough to have caused symptoms in a more critically ill patient. Shivering was severe, lasting until the hypertension was treated, and would have caused a marked elevation in the patient's oxygen consumption. We are unable to say why there was not a similar response to the first epidural injection of meperidine. We had withdrawn the catheter $1 \mathrm{~cm}$ between administrations, and one or other of the injections may have been into an epidural vein.

Increasing evidence is appearing in the literature to implicate the involvement of brain peptides in the central mechanisms of blood pressure control. There is interaction between agonists at opiate and monoaminergic receptors in the brain. ${ }^{3}$ This has been demonstrated clinically in the use of clonidine to block symptoms of opiate withdrawal. ${ }^{4}$

Endogenous opiates occur in the cardiovascular control centres, ${ }^{3}$ and when injected into the brain they have effects on blood pressure, prevented by competitive antagonists. ${ }^{5}$ Animal experiments are conflicting; different opiates either cause hypertension, or hypotension, depending on specific monoaminergic receptors stimulated, and on whether the animal is anaesthetised or not. ${ }^{3}$ Intra-ventricular injection of short chain peptides (leu and met encephalin) in awake animals, have been shown to result in hypertension and tachycardia. ${ }^{5}$ Opiate antagonists have been shown to abolish this hypertensive response. ${ }^{5}$

Epidural meperidine may well have a similar effect on the cardiovascular control centre, and cause hypertension. It may do this directly or perhaps indirectly by causing release of short-chain peptides.

It would have been interesting, but not clinically correct, to have left our patient's catheter in situ, repeat the injection of meperidine, and try to reproduce the hypertensive response. It would have been fascinating to have then used naloxone as an "antihypertensive" drug. Hypertension, however, may have become more severe with reversal of analgesia, and the use of naloxone was therefore not clinically appropriate.

We should not assume that icardiovascular stability is always a feature of the use of epidural narcotics. It is prudent to watch for blood pressure changes when using epidural opiates, especially in the critically ill, who may not tolerate acute changes in their cardiovascular parameters.

\section{Acknowledgement}

We are grateful to Miss Cathy Colligan for preparing the manuscript.

\section{References}

1 Shackford SR, Virgilio RW, Peters RM. Selective use of ventilator therapy in flail chest injury. $J$ Thorac Cardiovasc Surg 1981; 81: 194-201.

2 Johnston, JR, McCaughey $W$. Epidural morphine: a method of management of multiple fractured ribs. Anaesthesia 1980; 35: 155-7.

3 Unger T, Ganten D, Lang RE, Rascher W. Brain peptides and blood pressure control. Trends in Pharmacological Sciences. 1981; Nov: 289-93.

4 Gold MS, Redmond DE, Kleber HD. Clonidine in opiate withdrawal. Lancet 1978; 1: 929-30.

5 Schaz K, Stock G, Simon W et al. Enkephalin effects on blood pressure, heart rate, and baroreceptor reflex. Hypertension 1980; 2: 395-407. 


\section{Résumé}

Un homme de 76 ans qui était hospitalisé pour un volet thoracique a developpé une tachycardie, de l'hypertension et des frissons durant l'administration de demeral pour voie epidurale. Son hypertension étair sevère at a duré 40 minutes jusqu' au moment ou il a été traité avec des alpha-bloqueurs.

La littérature nous fournit l'évidence de l'implication de certains opiacés endogènes dons le contrôle de la pression artérielle. Les peptides à courtes chaines (leu + met enkephaline) si injectés dans les ventricules ou pour voie intraveineuse ont été démontré comme causant l'hypertension et la rachycardie réversible par la naloxone. 